\title{
EFEK INOKULASI TRYPANOSOMA EVANSI TERHADAP HISTOPATOLOGI JARINGAN SYARAF MENCIT (MUS MUSCULUS)
}

\author{
Epry Setiawan \\ Program Profesi Kedokteran Hewan, Fakultas Kedokteran Hewan \\ Universitas Wijaya Kusuma Surabaya \\ Email : evrysetia1@gmail.com
}

\begin{abstract}
The alms of this was analized research aims to analyze the damage of nerve tissue in the brain of mice (Mus Musculus) inoculated with Trypanosoma evansi. The animal used in this research was 27 male mice. The plan used in this research was the random complete plan (RAL) with one control group and two experimental groups used nine repetitions. Control group (PO) was given aquades, Pl group was inoculated with Trypanosoma evensi $0,2 \times 104 \mathrm{ml}$ by intraperitoneal, and then P2 group was inoculated with Trypanosma evansi $0,2 \times 104 \mathrm{ml}$ by subcutan. In the fourth day after inoculated the mice were sacrificed and taken the brain organ to make histopathology blood smear. The lesi result was analyzed by using scoring Kennedy method, it showed the result, there was a change of histopathology of nerve tissue in the brain organ of mice (Mus Musculus), it was lesion meningitis 33\% was in the control group, 100\% was in the experimental group 1 (P1), 100\% was in the experimental group $2(P 2)$. Perivascullar cuffing was $0 \%$ in the control group, 100\% was in the experimental group 1, and $88 \%$ was in the experimental group 2. The gained data was processed by using Statistical Program For Science (SPSS) with KrusskallWallis Test method and then with Mann-Whitney Test method. The result showed the real differences $(P \leq 0,01)$ between control group and experimental group 2 .
\end{abstract}

Keyword : Trypanosoma evansi, surra, meningitis, perivascular cuffing, gliosis, mice (Mus musculus).

\section{PENDAHULUAN}

Trypanosomiasis atau surra yang disebabkan oleh Trypanosoma evansi adalah merupakan salah satu penyakit hewan menular pada ternak kuda danruminansia besar, khususnya ternak sapi dan kerbau. Penyebaran Trypanosomaevansi (T.evansi) sangat luas hampir di seluruh pulau besar di Indonesia dan dapatmenyerang berbagai jenis ternak dan satwa liar (Mastra, 2011). Protozoa ini mengeluarkan sejenis racun yang disebut trypanotoksin yang dapat mengganggu hewan yang terinfeksi (Tjahayati dan Husniyati, 2012). Kasus surra pertama kali dilaporkan di Indonesia pada tahun 1897 pada seekor kuda di Semarang, Provinsi Jawa Tengah. Kemudian pada tahun 1898 terjadi wabah penyakit surra di Karesidenan Tegal, yang memakan korban sebanyak 500 ekor kerbau dari 7000 populasi dan pada tahun 19001901 terjadi wabah penyakit surra di
Karesidenan Pasuruan provinsi Jawa Timur. Setelah itu dalam kurun waktu 60 tahun penyakit berlangsung secara sporadis dan dilaporkan berbagai kasus berdasarkan pemeriksaaan klinis (Mastra, 2011). Trypanosoma evansi mempunyai inang yang beragam dari hewan liar sampai hewan domestik yang mempunyai nilai ekonomi yang penting dengan berbagai tingkat kerentanan yang berbeda. Diantara hewan domestik yang rentan adalah kuda, sapi, kerbau, kambing, anjing, dan kucing. Sedangkan pada hewan liar yang rentan adalah badak dan rusa. Hewan coba seperti tikus dan mencit juga sangat peka terhadap infeksi Trypanosoma evansi (Fahrimal, 2013). Inokulasi pada mencit (mouse inoculation) sebagai salah satu hewan coba yang sensitif terhadap surra merupakan metode yang sensitif untuk mendeteksi penyakit surra kronis dan sudah dibuktikan oleh para ahli. Disamping itu, mouse inoculation juga dipakai untuk 
propagasi Trypanosoma evansi untuk keperluan lebih lanjut seperti uji patogenesitas, pembuatan vaksin, dan uji imunologi (Fahrimal, 2013). Parasit ini memanfaatkan glukosa dan oksigen untuk multiplikasi mengakibatkan penipisan metabolit yang mengakibatkan perubahan degenaratif pada host. Perubahan selanjutnya berkembang diorgan baik karena kerusakan sel yang disebabkan oleh racun yang dikeluarkan oleh parasit, atau karena reaksi imunologi. Meskipun T.evansi adalah sebuah haemoprotozoa, akan tetapi bentuk visceral juga ditemukan dalam hati, lobus optik, hati, ginjal, paru-paru, dan otak (Singh bal, et all, 2012). Sistem syaraf termasuk sistem syaraf pusat (otak-sumsum tulang belakang) dan syaraf perifer. Sistem syaraf pusat terdiri atas milyaran sel neuron (sel syaraf) yang menerima dan menyalurkan rangsangan ke otot dan organ. Sistem syaraf pusat (SSP) memiliki sel yang khas, dan terminologi yang digunakan untuk menggambarkan perubahan cytopathogical berbeda dengan jaringan lain. Sel-sel saraf dengan mempunyai kerentatan terhadap cidera (Solfaine, 2013). Oleh sebab itu, bila sel saraf mengalami kerusakan maka terjadi gangguan penerimaan rangsangan ke otot dan organ, maka terjadi inkoordinasi. Pada penelitian ini digunakan sampel otak untuk melihat gambaran histopatologi mencit (mus musculus) yang telah diinokulasi Trypanosoma evansi karena otak termasuk dalam sistem saraf pusat yang mengalami gangguan syaraf pada gejala klinis yang ditimbulkan oleh Trypanosoma evansi. Oleh karena itu perlu dilakukan penelitian untuk melihat gambaran histopatologi jaringan syaraf pada organ otak mencit yang telah diinokulasi Trypanosoma evansi

\section{METODE PENELITIAN}

Hewan coba yang digumakan dalam penelitian ini adalah mencit (Mus musculus) dengan jenis kelamin jantan, sebanyak 27 ekor, dengan kisaran umur 2-3 bulan, dan berat badan 25-30 gram. Bahan yang digunakan adalah $\mathrm{NaCl}$ fisiologis dan mencit yang terinfeksi Trypanosoma evansi dari BBalivet, Bogor sebanyak 0,2x 104 trip/ml. Kholoform digunakan untuk melakukan euthanasi sebelum dilakukan nekropsi dan buffer formalin $10 \%$ digunakan untuk mengawetkan sampel otak setelah dilakukan nekropsi yang akan dibuat preparat. Pengambilan otak mencit dilakukan pada hari ke-4 pasca infeksi parasite T.evansi dilakukan euthanasi menggunakan khloroform secara inhalasi. Sampel otak dikumpulkan dari masingmasing perlakuan. Sampel otak kemudian dimasukan kedalam pot plastik ukuran $50 \mathrm{cc}$ yang sudah berisi larutan buffer formalin $10 \%$, selanjutnya dilakukan pembuatan preparat histologi dengan teknik pewarnaan Haemoxylin dan Eosin (HE). Mencit yang sebelumnya sudah terinfeksi oleh Trypanosoma evansi dari Balitvet Bogor diambil sampel darah, lewat vena lateral dari ekor. Teknik pengambilan darah dengan sebelumnya mencit dihandling, pegang mencit pada ekornya dengan tangan kanan, biarkan mereka mencengkram lantai dengan kaki depannya. Dengan tangan kiri dijepit tengkuk mencit diantara jari telunjuk dan jari tengah (bisa dengan jari telunjuk atau ibu jari). Potong bagian 1/3 pangkal ekor lalu masukan pada tabung heparin. Dapat dilakukan lewat jantung/intracardiac diantara costai ke dua dan ketiga. Sampling diawali dengan nekropsi hewan coba dan dilanjutkan pengambilan organ. Organ yang diambil adalah otak (cerebrum dan cerebellum).

Seluruh otak dimasukkan dalam cairan fiksatif Buffered Neutral Formalin (BNF) 10\%, setelah 2 hari organ otak akan mengeras. Dilakukan pemotongan jaringan dimasukan kembali ke BNF $10 \%$ selama $3 \times 4$ jam, kemudian dipotong lebih tipis dengan ketebalan sama, lalu dimasukan kedalam kaset dan siap diproses dalam Tissue Processor

Seluruh kelompok diadaptasi selama seminggu sebelum dilakukan perlakuan. Setiap kelompok dipelihara dalam kandang terpisah diberi makan dan minum secara adlibitum. Kelompok kontrol sebagai plasebo tidak diberi perlakuan, hanya diberi Nacl fisiologis. Kelompok P1 diinokulasi Trypanosoma evansi injeksi secara intraperitoneal dengan dosis 0,2x104 trip/ml. Sedangkan P2 diinokulasi Trypanosoma evansi injeksi secara subcutan dengan dosis $0,2 \times 104$ trip/ $\mathrm{ml}$.

Inokulasi Trypanosoma evansi secara intraperitoneal dan subcutan menggunakan spuit $1 \mathrm{cc}$. Setelah dilakukan adaptasi inokulasi 
dilakukan pengambilan darah untuk pengamatan derajat infeksi Trypanosoma evansi pada hari ke-1 dan hari ke-3 pasca inokulasi. Darah yang diambil diteteskan pada objek glass ditambah larutan $\mathrm{NaCl}$ fisiologis ditutup dengan cover glas lalu dilakukan pengamatan menggunakan mikroskop. Mencit dilakukan euthanasi setelah hari ke-4 berpatokan pada derajat infeksi parasitemia 4+ pasca inokulasi menggunakan kholoform secara inhalasi dan dinekropsi untuk semua populasi mencit. Kemudian diambil organ otaknya dimasukan kedalam pot plastik ukuran $50 \mathrm{cc}$ yang sudah diisi dengan bufer formalin $10 \%$.

\section{HASIL DAN PEMBAHASAN}

Pengambilan sampel organ otak dan sediaan histopathologi organ otak yang telah di inokulasi Trypanosoma evansitelah dilakukan, selanjutnya dilakukan pembacaan gambaran histopatologi menggunakan mikroskop cahaya dengan merk Nikon 600L yang dilengkapi dengan digital kamera DS Fi2 300 megapixel dan soft ware pengolah gambar nikon image system. Metode skoring derajat kerusakan otak pada pemeriksaan ini dilakukan menurut metode (Kennedy et al, 1997). Adapun hasil analisis, rerata, dan presentase hasil skoring pemeriksaan histopatologi kelmpok kontrol(P0), perlakuan 1 $(\mathrm{P})$, perlakuan $2(\mathrm{P} 2)$ terlampir di bawah ini.

Tabel 1 Persentase (\%) lesi meningitis (M), perivascular cuffing (PC), gliosis $(\mathrm{G})$ Kontrol (P0), Perlakuan 1 (P1), Perlakuan 2 (P2)

\begin{tabular}{lccc}
\hline Kelompok & \multicolumn{3}{c}{ Lesi } \\
& M & PC & G \\
\hline P0 & 33 & 0 & 0 \\
P1 & 100 & 100 & 100 \\
P2 & 100 & 88 & 88
\end{tabular}

Berdasarkan tabel dan diagram diatas presentase lesi pada jaringan otak mencit pada P0 yang tidak diberi perlakuan terdapat meningitis $33 \%$ tetapi tidak terdapat kerusakan pada perivascullar cuffing (PC) dan gliosis (G). Pada P1 yang di inokulasi Trypanosoma evansi melalui intraperitoneal terdapat meningitis $100 \%$, perivascullar cuffing $100 \%$ dan gliosis
$100 \%$ di jaringan otak mencit, sedangkan pada P2 yang di inokulasi Trypanosoma evansi melalui subcutan mengalami meningitis $100 \%$,perivascullar cuffing $88 \%$, dan gliosis $88 \%$.

Tabel 2. Hasil rerata Skoring Meningitis(M), Perivascullar cuffing (PC), dan gliosis (G). Berdasarkan Analisis statistic Kruskal-WallisTest.

\begin{tabular}{lccc}
\hline Kelompok & \multicolumn{3}{c}{ Lesi } \\
& $\mathrm{M}$ & $\mathrm{PC}$ & $\mathrm{G}$ \\
\hline P0 & 5,3 & 5,50 & 5,50 \\
P1 & 21,4 & 21,3 & 20,7 \\
P2 & 15,2 & 15,17 & 15,72
\end{tabular}

Trypanosoma evansi dapat memberikan perubahan gambaran histopatologi pada jaringan otak pada mencit. Perubahan tersebut mengalami Meningitis, Perivascular cuffing, dan Gliosis. Hasil presentase lesi pada gambaran histopatologi organ otak mencit (Mus musculus) yang di inokulasikan Trypanosoma evansi menunjukan hasil nilai presentase meningitis pada kelompok P0 (33\%), pada perlakuan P1 dan perlakuan P2 (100\%) (tabel 1).Dari delapan belas sampel tingkat keradangan berbeda berdasarkan rerata hasil skoring, karena nilai kerusakan pada perlakuan P1 yang di injeksi secara intraperitonealhasil rerata skoring lebih tinggi dibandingkan dengan perlakuan P2 yang di injeksi melaui subcutan.

Hasil penelitian ini sejalan dengan pendapat Biswas. D, (2010) ditemukan keradangan lesi nekrotik pada meninges dari tikus yang di infeksi Trypanosoma evansi. Pada kelompok control yang tidak di inokulasi trypanosoma juga mengalami peradangan dari meninges, hal ini terjadi dikarenakan beberapa faktor. Faktor penyebab terjadinya peradangan dari meninges tersebut menurut (Israr, 2008) salah satu penyebabnya oleh bakteri, virus, riketsia, atau protozoa. Anoxia, racun mercury, manganase, carbon monoksid, alkohol, sodium klorid, kekurangan vitamin B1, vitamin E dan gangguan metabolik juga merupakan salah satu faktor penyebab keradangan (Solfaine, 2013). Presentase rata-rata Perivascular cuffing pada kelompok P0 (0), perlakuan P1 (100\%), perlakuan P2 (88\%). Rata-rata hasil skoring dan presentase antara perlakuan $\mathrm{P} 1$ dan perlakuan $\mathrm{P} 2$ 
terjadi perbedaan sangat nyata. Kelompok perlakuan P1 mengalami tingkat kerusakan Perivascular cuffing lebih tinggi dari perlakuan P2 dilihat dari nilai scoring dan presentase. Perivascular cuffingdari pembuluh darah jaringan otak di tunjukan pada (Gambar 4.5), terlihat jelas ilfiltrasi sel-sel limfosit di dalam pembuluh darah. Terjadi kerusakan ringan pada sel glia (gliosis) dan ilfiltrasi sel limfosit yang sangat sedikit pada perlakuan 2 (Smuts. C, 2009).

Perubahan yang terjadi di dalam pembuluh darah otak disebabkan karena zat-zat beracun yang dikeluarkan oleh Trypanosoma evansi. Perubahan patologis di otak disebabkan iritasi konstan yang oleh adanya parasit atau racun yang di keluarkan oleh Trypanosoma (Singh Balet all, 2012). Hasil presentase ratarata yang mengalami Gliosis pada kelompok $\mathrm{P} 0$ (0\%), kelompok perlakuan P1 (100\%) dan kelompok perlakuan P2 (88\%). Kelompok P0 yang tidak di inokulasi tidak mengalami gliosis, sedangkan pada kelompok perlakuan P1 dan perlakuan P2 terdapat gliosis yang ditimbulkan oleh parasit. Hasil penelitian ini sesuai dengan pendapat Damayanti (1994) terdapat kerusakan pada otak anjing yang di infeksi Trypanosoma evansi berupa gliosis yang di tandai dengan perivascullar cuffing dengan infiltrasi oleh selsel limfosit (Gambar 4.6).

Encephalitisatau gliosis juga telah ditemukan pada kambing dan kerbau yang terinfeksi Trypanosoma evansi (Singh balet all, 2012). Hasil inokulasi trypanosoma evansi antara kelompok perlakuan P1 yang melalui rute intraperitoneal lebih cepat tingkat parasitemianya dibandingkan dengan perlakuan P2 yang melalui rute subcutan. Tikus yang diinokulasi Trypanosoma evansi melalui rute subcutan menunjukan jangka waktu parasitemia lebih lama dibandingkan dengan rute intraperitoneal yang terlihat dalam waktu

lima hari. Hal ini disebabkan perbedaan karena perbedaan daya absorbsi. Pada intraperitoneal permukaan absorbsi lebih luas dan banyak pembuluh darah di mesenterium, sedangkan pada subcutan daya absorbsi lebih lama dikarenakan harus melalui lapisan kulit terlebih dahulu sebelum masuk kepembuluh darah (D’Archivio, 2013).
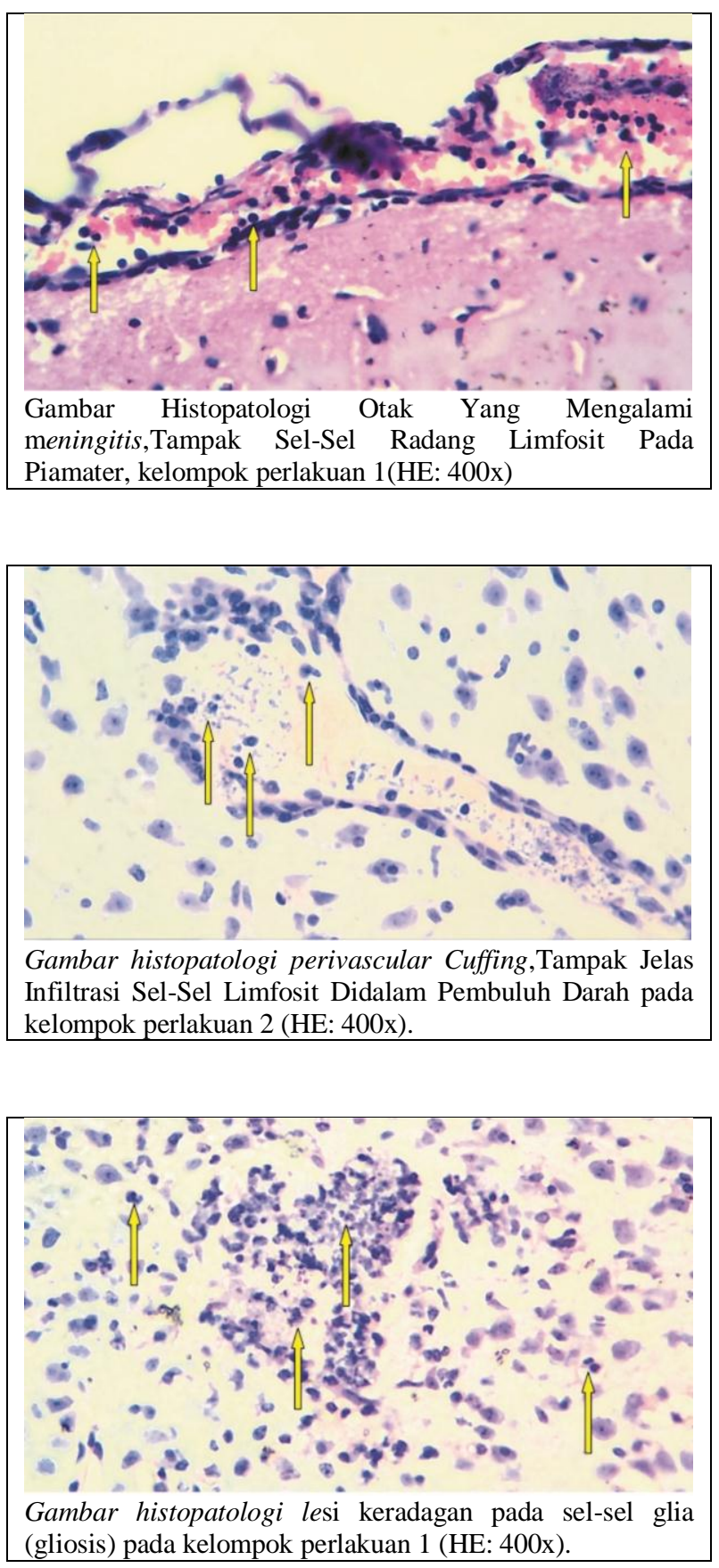

Perjalanan penyakit trypanosoma terjadi dengan cara Trypomastigot masuk ke dalam tubuh hospes melalui gigitan lalat. Berkembang biak sehingga menyebabkan inflamasi lokal pada tempat gigitan. Parasit tersebar melalui aliran darah, sampai pada semua jaringan. Mulamula akan tampak perbesaran kelenjar limfe ini dikenal dengan stadium akut, jika tidak terobati akan masuk pada stadium kronis, parasit sudah 
menginvasi pada susunan saraf pusat. Stadium akut diawali dengan gejala prodormal yang tidak spesifik, demam tidak teratur, sakit kepala, sakit sendi dan otot serta kerusakan (rash) pada kulit. Pada stadium kronis sudah mulai serangan pada susunan saraf pusat berupa meningo encephalitis difussa dan meningomyelitis (Natadisastra, 2009). Pada penelitian ini, mencit yang digunakan sebagai hewan coba penelitian juga mengalami gejala yang sama antara lain inkoordinasi gerak, anemia dan nafas berat. Mekanisme Trypanosoma evansimenginvasi jaringan otak, pertama kali Trypanosoma evansimasuk ke dalam tubuh melalui pembuluh kapiler, masuk ke pembuluh darah besar (Vena) dan akan di pompa oleh jantung ke seluruh tubuh termasuk ke jaringan otak. Pada pembuluh darah otak Trypanosoma evansiakan keluar untuk bermigrasi ke jaringan otak dengan melewati membran endotel, ruang perivascular dan membran parenkim untuk menyerang parenkim otak (D’Archivio, 2013).

\section{KESIMPULAN}

Berdasarkan penelitian ini, dapat ditarik kesimpulan bahwa :

1. Inokulasi trypanosome sp. intraperitoneal menyebabkan lesi histologis berupa meningitis, perivascular cuffing dan encephalitis.

\section{DAFTAR PUSTAKA}

Astuti, Rr.U, Rismawati, D.,Hidayati, S., Suntoro, S.H.2007. Pemanfaatan Mindi (Melia Azedarach L.) Sebagai Anti Parasit Trypanosoma evansi dan Dampakya Terhadap Struktur Jaringan Hepar dan Ginjal Mencit.

Kemajuan terkini penelitian klaster sainsteknologi : Fak.biologi UGM.

Biswas, D., A.Choudhury dan K. Kumar Misra. 2010. Histophatology Of Trypanosoma (Trypanozoon) Evansi Infection In Bandicot Rat.II. Brains And Choroid Plexus. Departemen Of Zoology, University of Calcuta. 27-37

Cahyaningsih, U. 2013. Buku Ajar Parasitologi. Departemen Ilmu Penyakit Hewan dan
Kesmavet Fakultas Kedokteran Hewan Institut Pertanian Bogor.

D'Archivio, S., A. Cosson., M. Medina., T. Loug., D. Minoprio and S. Goyard. 2013. NonInvasif In Vivo Study Of The Trypanosona Vivax Infection Proses Consolidates The Brain Comitment In Late Infections. Plos negl trop dis. 7(1): E 1976

Dellman, H.D dan Brown, E.M. 1989. Buku Teks Histologi Veteriner. Edisi ke-3.Universitas Indonesia Press : Jakarta.

Dongga, R.E. 2013. Adopsi Teknologi Pengendalian Penyakit Surra Oleh Peternak Kuda di Kabupaten Sumba Timur, Nusa Tenggara Timur. Tesis.Universitas Udayana: Denpasar.

Dyce, R.D. 2002. Tekt Book Of Veterinary Anatomy. 3rd. Philadelphia: Saunders.

Fahrimal, Y.,M.D. Saad dan H. Budiman. 2013. Inokulasi Trypanosoma Evansi Pada Mencit (MusMusculus) Strain BALB.C Yang Berasal Dari Sapi Lokal. Jurnal Medika Veterinaria: Banda Aceh.

Gatner, L.P, Hiatt, J.L, Strum, J.M. 2012. iologi Sel Dan Histologi. Edisi Ke-6. Alih Bahasa Dr. Fajar Arifin Guna Wijaya. Tangerang: Binarupa Aksara.

Smuts., C.M. 2009.thesis. Development Of Todis To Inprove The Detection Of Trypanosoma Evansi In Australia. Murdoch University: australia. Hal:124

Solfaine, Rondius. 2013. Pengantar Patologi Veteriner II. Proyeksi Indonesia:Yogyakarta. Subronto. 2006. Penyakit Infeksi Parasit Dan Mikroba Pada Anjing dan Kucing. Gadjah Mada University Press: Yogyakarta. Sutanto I, Ismid I.S, Sjarifuddi P.K, dan Sungkar. 2008. Buku Ajar Parasitologi Kedokteran.Edisi Ke-4, Balai Penerbit FK UI: Jakarta. 